\section{Felicidades maestros}

Cada 30 de abril celebramos el Día del Maestro, fecha en la que recordamos con especial afecto a aquellos que mediante su visión de enseñanza, su sabiduría y amor a la profesión, nos contagiaron el deseo de constante superación y alimentaron nuestra curiosidad científica, poniendo todo de sí por formar una generación de cirujanos con sentido crítico, humanistas y con el arte de la cirugía a la orden para servir a quien la necesite.

Grandes maestros de la cirugía paraguaya han impreso sus experiencias en nuestra revista y nos han enriquecido en nuestros congresos, pero lo más importante es que han caminado a nuestro lado en el día a día de la vida hospitalaria. Hasta me animo a decir que algunos afortunados pudimos inclusive tener el honor de ser llamados amigos por estos brillantes próceres de la enseñanza.

También nos han dejado dos deberes; el primero para con nosotros mismos, el cual es tratar de igualarlos, o tal vez, incluso ser mejores, tarea difícil pero que puede ser llevada a cabo con el mismo sacrificio que ellos hicieron; y lo segundo, igualmente importante al anterior, que es la de transmitir a los cirujanos más jóvenes lo enseñado por ellos y lo aprendido por nosotros, la calidad científica y moral, que deben ser los pilares para consolidar a nuestra sociedad quirúrgica.

Este número de nuestra revista va dedicado a ellos, a nuestros maestros, a los que ya no están y a los que continúan apostando por una enseñanza de calidad humana y científica.

\section{Congratulations masters}

Every april 30, we celebrate Teacher's day, the date on wich we remember with special affection those who through their vision of theaching, their wisdom and love of the profession, infected us with the desire of constantly improve and nourished our scientific curiosity, pouring all of it self to form a generation of surgeons with a critical sense, humanist and the art of surgery to serve those who needed.

Great masters of paraguayan surgery have printed their experiences in our journal, and they have enriched us in our congresses, but most importantly, they have walk by our side in the day to day life in the hospital. I even dare to say that some fortunate people have had the honor of being called friends by these brilliant leaders of the teaching.

But also, they have left us two duties; the first for ourselves, wich is to try to equal them or maybe, even be better, a difficult task that can be carry out with the same sacrificed they did; and the second equally important to the previous one, which is to transmit to the youngest surgeons what was taught by them and learned from us, the scientific and moral quality, which should be the pillars to consolidate our surgical society.

This issue of our journal is dedicated to them, to our teachers, to those who are no longer here, and to those who continue to bet on a human and scientific teaching quality.

Congratulations Masters!

¡Felicidades Maestros! 